\title{
A multi-temporal mapping approach for improving the temporal and spatial characterization of landslide activity in clay-rich terrain
}

\author{
Sharon Pittau (1), Marco Pizziolo (2), Mauro Rossi (3) \& Francesco Brardinoni (1)
}

(1) Department of Biological, Geological and Environmental Sciences, University of Bologna, Bologna, Italy.

(2) Servizio Geologico Sismico e dei Suoli, Regione Emilia-Romagna, Bologna, Italy.

(3) CNR-IRPI, Perugia, Italy.

Corresponding author e-mail: sharon.pittau2@unibo.it

Document type: Article.

Manuscript received 20 April 2021; accepted 16 June 2021; editorial responsibility and handling by F. Troiani.

\section{ABSTRACT}

In mountain, clay-rich physiographic settings of the Northern Apennines, earth slides and earth flows are dominant processes of hillslope sediment transfer, which cause hazard and pose risk to lives and man-made structures. In Emilia-Romagna (E-R), information drawn from a region-wide inventory is customarily used for assessing landslide hazard potential and partly guides decision making on land management and urban planning. However, the inventory's historical (i.e., post-1954) degree of completeness is presently unknown. To address this gap, we integrate and compare the existing E-R inventory with a multi-temporal landslide mapping approach at four selected study sites of the Sillaro River basin, where we perform visual interpretation of thirteen sequential aerial photo sets in the 19542020 period and conduct confirmatory fieldwork. Specific objectives include evaluating the advantages of higher resolution mapping for characterizing (i) landslide extent, geometry and activity through time; and (ii) landslide interaction with the drainage network. With reference to the E-R inventory, multi-temporal mapping allowed reducing mapping uncertainty through the identification of additional first occurrences and recurrences (up to a factor of 5), additional mapped landslide area (up to a factor of 12), and combined footprint area (up to a factor of 9). Our findings indicated that the proposed approach does not always result in mapping larger (or smaller) landslide polygons, or previously undetected landslides, but provides insights on process understanding. Therefore, an added value of this mapping approach lies in its ability to detect different styles of landsliding and define most likely scenarios of evolution at the site scale. Insights were drawn through detection of: (i) headscarp upslope migration (or revegetation); (ii) newly formed gully channels and/or revegetation on landslide depositional features; and (iii) changes at landslide terminus, which allowed identifying new sediment pulses, exact delivery targets (e.g., fan, valley floor, and stream channel), as well as induced changes in channel bed texture and geometry.

KEYWORDS: Landslides, landslide inventory, temporal resolution, recurring activity, sediment delivery to streams.

\section{INTRODUCTION}

Multi-temporal landslide inventories are efficient tools for the rapid evaluation of geomorphic change and landslide-driven sediment flux over large areas (Reid \& Dunne, 1996; Brardinoni et al., 2012), as well as for assessing sediment supply to stream channels (Finnegan et al., 2019; Schuerch et al., 2006), relevant disturbance regimes (Nakamura et al., 2000), effects on channel-reach morphology and geometry (Brummer \& Montgomery, 2003; Green et al., 2013; Hassan et al., 2019) and hazard potential (Guzzetti et al., 2005). Their basin-to-regional approach complements site-specific monitoring efforts on single landslides (e.g., Baum \& Reid, 1995; Berti \& Simoni, 2010; Corsini et al., 2009; Nereson \& Finnegan, 2018), and radar interferometry investigations on slow-moving bodies (e.g., Bayer et al., 2018; Bekaert et al., 2020; Colesanti \& Wasowski, 2006; Roering et al., 2009).

Multi-temporal landslide inventories may be compiled through integration of aerial photo and/or satellite imagery interpretation, field surveys, and historical documentation. Methods adopted in the compilation -- which depend on the study objectives, available resources, spatial and temporal resolution needed, and the spatial extent to be investigated (Guzzetti et al., 2000) -- will affect the quality and the completeness of the inventory maps, hence the reliability of the derived (basic or applied) products.

In Emilia-Romagna (E-R), the regional Geological Survey has compiled and has been managing a regionwide multi-temporal landslide inventory (Regione EmiliaRomagna, 2021), which is intended as a complementary tool to guide land planning. The bulk of the inventory, including the attribution of the activity status, was built between the mid 1980's and late 1990's, through stereoscopic inspection of historical aerial photo sets (i.e., 1954, 1969, 1976 and 1996) and complementary field visits. The inventory was digitized in 2005 and since then has undergone annual updating via manual delineation of landslide polygons on post-1996 aerial orthophoto sets and Google Earth imagery, as well as directly, drawing information from field surveys, local newspapers, historical archives, and technical reports associated with slope stability monitoring programs (Piacentini et al., 2018).

In the inventory, each landslide is mapped as a polygon feature, where the polygon outline comprises the total (i.e., initiation, transport and deposition zones) landslide area. Each polygon is characterized by categorical and geometric attributes, such as movement type (e.g., fall, flow, slide, complex), state of activity (i.e., active or dormant), scar area, and scar length (Table 1). Attribution of activity should be regarded as indicative, except otherwise documented by direct historical information. Specifically, classification of landslide features in active or dormant is mostly based on their morphologic expression as interpreted on aerial photos. 
TABLE 1

Landslide attributes of the Emilia-Romagna inventory.

\begin{tabular}{|c|c|}
\hline Attribute & Category \\
\hline Landslide type & $\begin{array}{l}\text { Rock fall } \\
\text { Slide } \\
\text { Earth flow } \\
\text { Debris flow } \\
\text { Deep-seated gravitational slope deformation (DGSD) } \\
\text { Complex } \\
\text { Indefinite }\end{array}$ \\
\hline State of activity & $\begin{array}{l}\text { Active } \\
\text { Dormant }\end{array}$ \\
\hline Geometry & $\begin{array}{l}\text { Area } \\
\text { Length }\end{array}$ \\
\hline
\end{tabular}

To date, the inventory comprises 80,985 landslides, including respectively 44,377 active and 36,608 dormant failures (Fig. 1). Collectively, landslides occupy an area of about $2,600 \mathrm{~km}^{2}$, out of the $10,500 \mathrm{~km}^{2}$ hilly and mountain terrain of Emilia-Romagna. Prevalent movement types are earth slides and earth flows that typically recur on pre-existing scars (Bertolini \& Pizziolo, 2008) and mainly involve clay-dominated Ligurian Units (Berti et al., 2012; Simoni et al., 2013; Pizziolo et al., 2015).

Considering the inventory's main purpose, its regional extent and available resources, the updating process is conducted each year in different areas, mainly where landslides have caused damage and/or pose immediate risk to structures and infrastructure, or where ad hoc contingent land planning is needed. Therefore, information such as date of first recorded occurrence, subsequent recurrences and possible cause of activation is limited to a subset $(\mathrm{n}=$ 2,558 ) of so-called "historical" landslide polygons. When the size of a historical activation is too small to be drawn on a 1:5000 map, or the exact location (or geometry) is uncertain, the landslide is treated as a point feature in the database (Piacentini et al., 2018).

With reference to post-1954 landslide activity, the degree of E-R inventory completeness, is presently unknown. This is a critical shortcoming, both for addressing basic scientific questions on landscape evolution (e.g., Finnegan et al., 2019) and for tackling more applied issues, such as landslide hazard assessment (e.g., Wieczorek, 1984) or watershed sediment management. In this paper, we aim to explore the advantages of adopting a higher temporal resolution mapping for (i) documenting landslide extent and activity through time; and (ii) landslide interaction with the drainage network. To this purpose, we integrate and compare the existing EmiliaRomagna inventory with systematic visual inspection of all available historical aerial photo sets and confirmatory fieldwork. In particular, we focus on four landslide sites within the Sillaro River, a mountain basin representative of the physiographic, clay-dominated context of the Northern Apennines. The four study sites were selected so to encompass a range of characteristics including system size and complexity, landslide type, landslide lateral confinement, and sediment delivery to the drainage network (Fig. 2). Accordingly, they include simple,

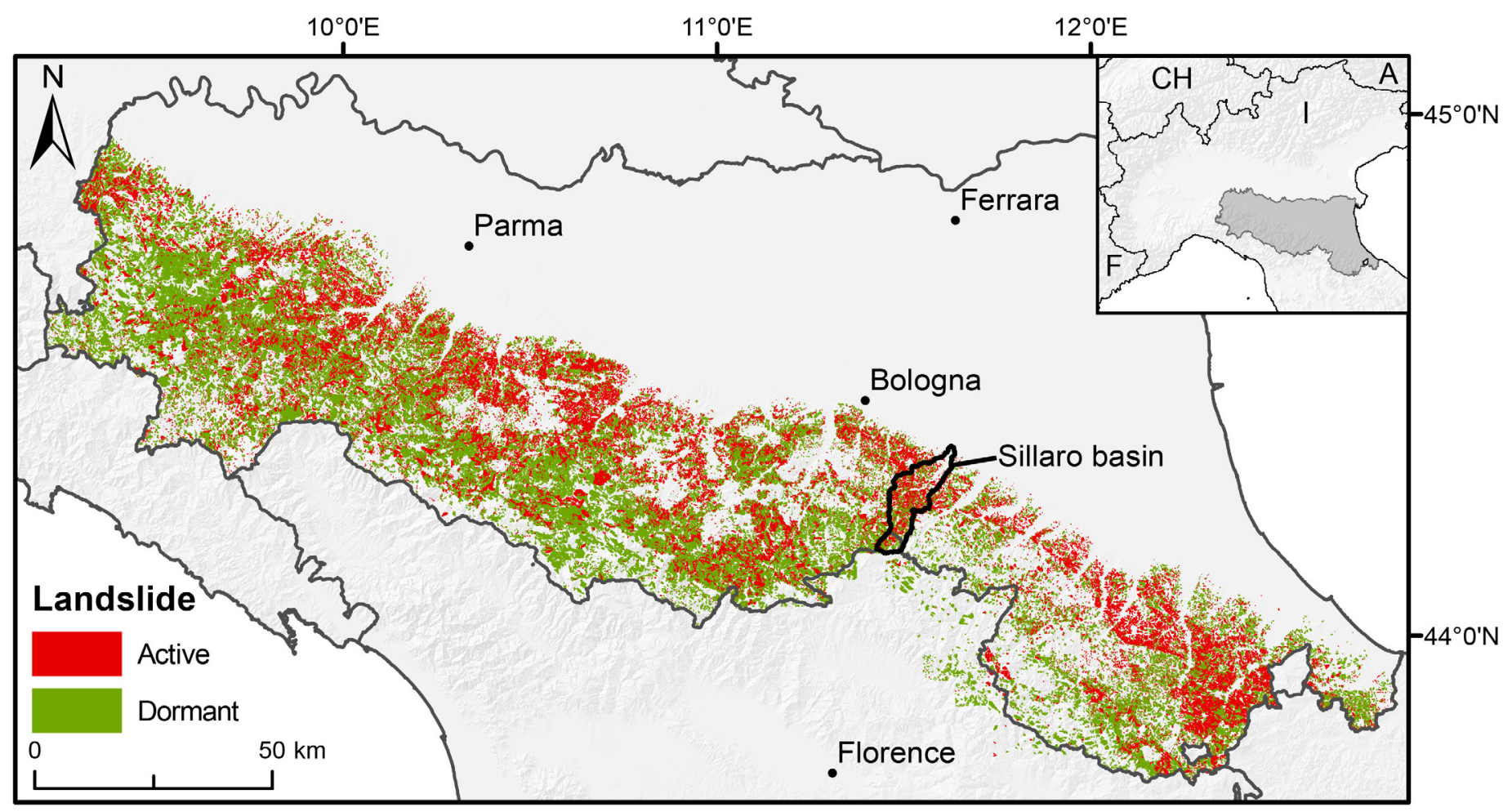

Fig. 1 - Emilia-Romagna landslide inventory map (version updated on January $1^{\text {st }} 2021$ ). Solid grey linework indicates coastlines and regional administrative boundaries, black open polygon delimits the Sillaro River basin. The inset shows the location of the Emilia-Romagna within Italy. 


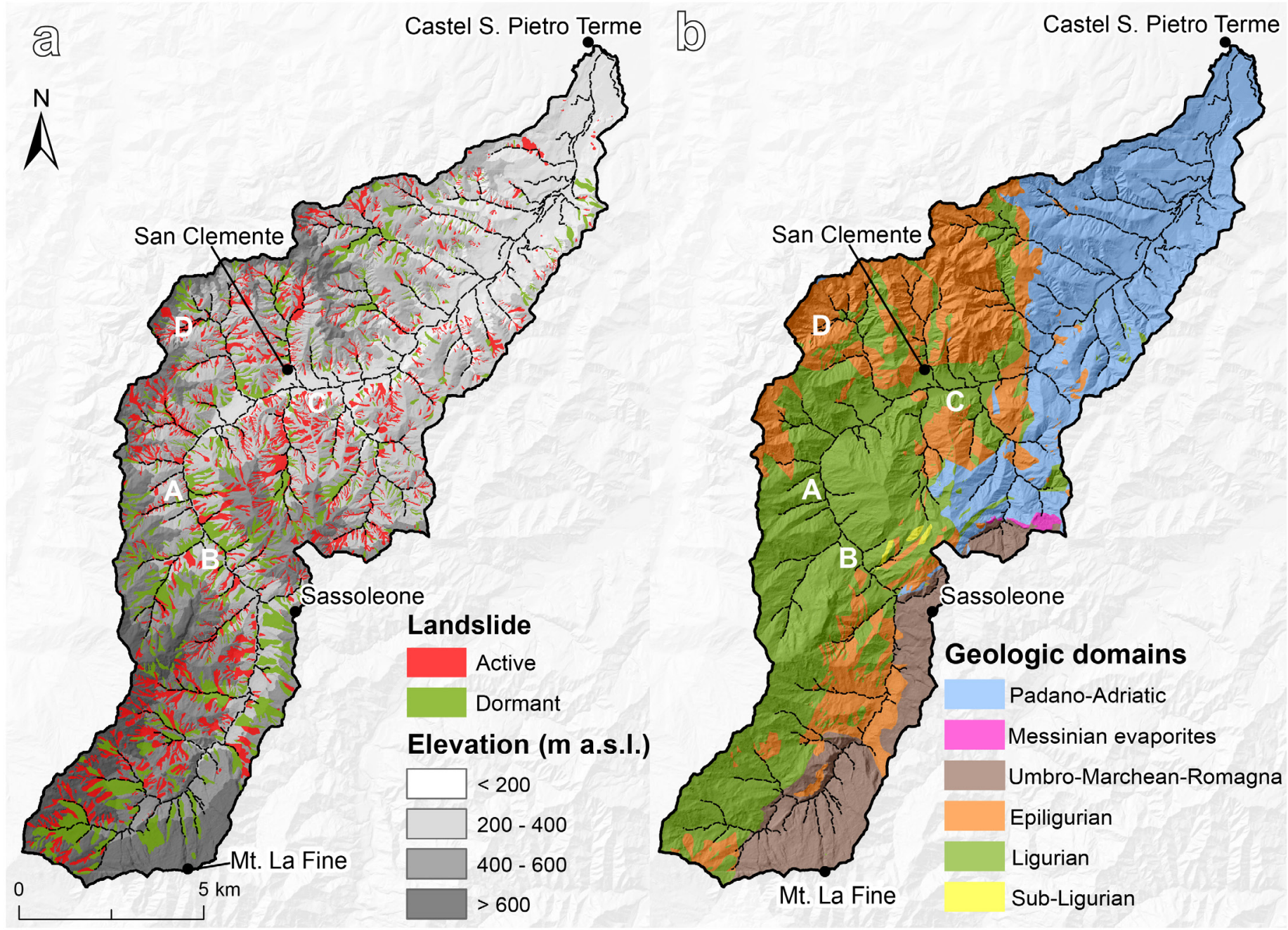

Fig. 2 - Maps of the Sillaro River basin showing: (a) active (red polygons) and dormant (green polygons) landslides of the Emilia-Romagna inventory, as well as elevation bands shown with different grey tones; and (b) geological domains. Capital letters indicate the four sites of interest.

unconfined earth flow (site A) and earth slide (site B) that interact directly with the Sillaro River, a channelized earth flow that interferes with a road (site $\mathrm{C}$ ), and three earth flows that converge towards an old landslide deposit and interact with the secondary ephemeral drainage network (site D) (Fig. 3).

\section{STUDY AREA}

The mountain portion of the Sillaro River basin (139 $\mathrm{km}^{2}$ ), Northern Apennines, originates at the orogen divide in Mt. La Fine (993 m a.s.l.), and develops northeast down to the town of Castel San Pietro Terme (56 $\mathrm{m}$ a.s.l.) in Emilia-Romagna, within the Bologna Metropolitan Area (Fig. 2). The channel main stem displays a complex planform structure, characterized by a large northward bend in its middle portion. The area has a Mediterranean climate with distinct cold and dry seasons, and mean annual rainfall of $824 \mathrm{~mm}(1990-2020)$ at San Clemente (166 m a.s.l.) meteorological station (ARPAE, 2021).

According to the Emilia-Romagna inventory, the basin hosts 1,981 landslides (1,247 active and 734 dormant), for a combined area of $34 \mathrm{~km}^{2}$ (Fig. 2a). Among these, 13 hold historical records of occurrence, including study site C.

The study basin is located at a key regional geologic transition, where the Ligurian Unit (Cretaceous-Eocene) and the Umbro-Marchean-Romagna succession (MiocenePleistocene) come into contact in proximity of its southeastern side (Benini et al., 2009; Bettelli et al., 2012; Zattin et al., 2002) (Fig. 2b). Bedrock geology consists primarily of alternations of marls and clays of the Ligurian (Cretaceous-Eocene), Sub-Ligurian (Eocene-Oligocene) and Epiligurian (Eocene-Miocene) domains in the upperto-mid portions of the basin, and of clays and sands of the Padano-Adriatic (Upper Messinian-Pleistocene) domain in the remainder lower part (Fig. 2b). In particular, tectonized clays of the Ligurian Unit, which underlain most part of the study landscape, incorporate large limestone blocks and exhibit chaotic texture. Foredeep turbidities of the Umbro-Marchean-Romagna succession (Marnoso-Arenacea Formation, Serravallian-Tortonian), consisting of sandstone-pelite alternations, outcrop on the south-eastern part (Fig. 2b). Of the four study sites, A, B and $C$ are underlain by Ligurian lithologies, whereas $D$ is characterized by Epiligurian substrates (Fig. 2b). 
Most of the basin likely underwent forest clearing in unknown historical times, with forest cover reaching a minimum immediately after Second World War. Since then, societal changes, including the abandonment of the countryside, have induced a substantial increase in forest cover (Preciso et al., 2012; Pavanelli et al., 2019). Today, land cover consists primarily of arable crops and meadows, which occupy about one third of the basin, mainly in its mid-to-lower portions. Bushes and managed forest together cover about half of the basin, mainly at higher elevations, in the mid-to-upper portions of the basin, including terrain of the Marnoso-Arenacea Formation. Badlands, which accounts for over $12 \%$ in area, are clustered in the central part of the basin, in correspondence of Ligurian and Epiligurian lithologies. Urban areas are restricted along the distalmost parts of the Sillaro main valley floor, around Castel San Pietro Terme, which is the only town in the basin (Fig. 2).

\section{DATA COLLECTION AND METHODS}

Landslide identification and delineation at the four study sites was performed through visual inspection of ten sequential aerial photosets $(1954,1969,1976,1985-$ 88, 1996, 2000, 2006, 2008, 2011, and 2014), and Google Earth imagery (i.e., 2016, 2018 and 2020) (Table 2). We mapped the areal extent of each mass movement observed on optical imagery, setting a minimum level of landslide width detection of 4 meters. Below this threshold, it was not possible to consistently delineate the landslide perimeter, especially on the 1954 photos, due to coarse resolution and poor contrast. Landslide tracks were digitized in GIS environment on the sequential orthophoto mosaics. We first delineated polygons of total disturbed landslide area, which includes initiation, transport and deposition zones; then, when possible, we subdivided total disturbed area into initiation-transport and deposition polygons.
Recorded landslide attributes for each landslide polygon include: photo year of occurrence, landslide type, morphologic position at initiation (source), lateral confinement, and sediment delivery target at landslide terminus (sink) (Table 3). Photo year represents the minimum landslide age, where temporal constraint is given by the date of the preceding aerial photo set. Consequently, year of occurrence for landslides first identified in 1954 is unknown. Classification of landslide type follows the scheme proposed by Cruden \& Varnes (1996). We use the term terminus (as opposed to toe) to indicate the downslope end of visible landslide disturbance, since several cases did not exhibit a well-defined toe (e.g., Brardinoni et al., 2009).

Definition of morphologic position at initiation and sediment delivery target are important to identify sites of sediment production and delivery, and consequently the sediment transfer pathways (hereafter termed source-tosink pathways) that dominate on the hillslopes and along the steep ephemeral drainage network. Initiation positions include gully headwall and open slope sites. Following previous classification schemes (Maynard, 1991; Brardinoni et al., 2015), sediment delivery targets encompass four "natural" categories, listed in order of increasing sediment delivery potential (or deliverability), and an additional one associated to anthropogenic barriers. Categories include: (i) hillslopes (unchannelled topography); (ii) gully channels (v-notched, first and second order streams flowing on bedrock or on colluvial deposits) (Figures $3 \mathrm{c}$ and $3 \mathrm{~d}$ ); (iii) permanent tributaries (higher order streams with an alluvial channel bed that drain secondary valleys); (iv) main channels (i.e., the Sillaro River main stem) (Figures $3 \mathrm{a}$ and $3 \mathrm{~b}$ ); and (iv) roads, or other anthropogenic barriers that may prevent landslides from reaching the drainage network. An example of a source-to-sink pathway affected by man-made structures is provided in Fig. 3c. Here a channelized earth flow originates at a gully headwall, flows along a steep, confined gully channel and stops by a road, which was deflected downslope. Degree of lateral confinement was defined with reference to the transport

TABLE 2

Digital ortho-imagery used for multi-temporal landslide identification and mapping.

\begin{tabular}{lllll}
\hline Year & Nominal scale & Pixel size $(\mathbf{m})$ & Imagery type & Source \\
\hline 1954 & $1: 55,000$ & 1 & Black and white & Istituto Geografico Militare \\
1969 & $1: 15,000$ & 0.7 & Black and white & Regione Emilia-Romagna \\
1976 & $1: 13,000$ & 0.9 & Color & Regione Emilia-Romagna \\
$1985-88$ & $1: 25,000$ & 1 & Black and white & Regione Emilia-Romagna \\
1996 & 1 & Black and white & Regione Emilia-Romagna \\
2000 & 1 & Color & WMS GN* \\
2006 & 0.5 & Color & WMS GN* \\
2008 & 0.5 & Color & WMS E-R** \\
2011 & 0.5 & Color & WMS E-R** \\
2014 & 0.5 & Color & Regione Emilia-Romagna \\
2016 & 0.3 & Color & Google Earth \\
2018 & & Color & Google Earth \\
2020 & & Color & Google Earth \\
\hline
\end{tabular}

* Geoportale Nazionale: http://www.pcn.minambiente.it/mattm/servizio-wms/

** Geoportale Regione Emilia-Romagna: https://geoportale.regione.emilia-romagna.it/servizi/servizi-ogc/elenco-capabilities-dei-servizi-wms 
TABLE 3

Landslide attributes of the multi-temporal inventory (this study).

\begin{tabular}{|c|c|}
\hline ATTRIBUTE & CATEGORY OR UNITS \\
\hline Landslide size & Total disturbed area $\left(\mathrm{m}^{2}\right)$ \\
\hline Landslide type & $\begin{array}{l}\text { Earth flow } \\
\text { Earth slide } \\
\text { Complex }\end{array}$ \\
\hline Photo year of activity & From 1954 to 2020 (cf. Tab. 2) \\
\hline $\begin{array}{l}\text { Morphologic position at initiation } \\
\text { (Initiation zone) }\end{array}$ & $\begin{array}{l}\text { Gully headwall } \\
\text { Open slope }\end{array}$ \\
\hline $\begin{array}{l}\text { Lateral confinement } \\
\text { (Transport zone) }\end{array}$ & $\begin{array}{l}\text { Confined } \\
\text { Channelized } \\
\text { Unconfined }\end{array}$ \\
\hline $\begin{array}{l}\text { Sediment delivery target } \\
\text { (Deposition zone) }\end{array}$ & $\begin{array}{l}\text { Hillslope } \\
\text { Gully channel } \\
\text { Permanent tributary } \\
\text { Main channel } \\
\text { Anthropogenic barrier }\end{array}$ \\
\hline Headscarp activity & $\begin{array}{l}\text { Upslope migration } \\
\text { Revegetation }\end{array}$ \\
\hline Deposition lobe activity & $\begin{array}{l}\text { Gully incision } \\
\text { Revegetation }\end{array}$ \\
\hline Stream channel changes & $\begin{array}{l}\text { Occlusion } \\
\text { Avulsion } \\
\text { Bed coarsening }\end{array}$ \\
\hline
\end{tabular}

zone, where we distinguished between confined (mostly channelized) tracks and landslides that move down an unconfined hillside.

Recurring initiations from the same sites were also mapped and recorded, so that each mapped landslide was provided with a unique identifier, and a secondary one (i.e., equal for all landslides that originate from the same initiation site) was assigned to recurring landslides. Information about landslide recurrence is useful to evaluate landslide hazard (e.g., Crovelli, 2000; Guzzetti et al., 2006), sediment transfer through time (e.g., Hovius et al., 1997; Brardinoni et al., 2009), as well as potential rates of sediment recharge across the gully channel network (Bovis \& Jakob, 1999; May \& Gresswell, 2003). For recurring landslides, we noted whether the movement involved: (i) the entire track of an antecedent slope failure or only part of it; (ii) headscarp retreat; (iii) advance of an existing landslide terminus; and (iv) downslope stream channel changes. Within landslide deposition zones, we recorded the temporal pattern of revegetation and/or the development of gully channel incision. The former indicates the degree of site stability across photo years, the latter indicates the degree of ongoing fluvial reworking.
In the results, we will compare at each site our multitemporal mapping with that of the E-R inventory, where morphological scar changes (e.g., headscarp retreat, terminus advance or erosion, and downslope secondary activation) within a given landslide system are progressively incorporated in the pre-existing "old" polygon (i.e., change of polygon outline) as the inventory gets updated. We start from simple landslide systems and continue with increasingly larger and more composite configurations.

\section{RESULTS}

At site A, detailed multi-temporal mapping allowed: (i) integrating the three (active) landslide scars included in the E-R inventory (Fig. 4a) with additional ones, and (ii) showing that landslides are recurrent in nature. On 1954 photos, we could distinguish six landslide scars, whose year of last mobilization is uncertain. In this study, existing (active) polygon outlines were also enlarged (cf. Fig. 4a and 4b). Overall, landslide area in 1954 adds up to $48,700 \mathrm{~m}^{2}$, as opposed to $5,700 \mathrm{~m}^{2}$ in the existing inventory. In subsequent photo years (i.e., 1969, 1988, 2011, 2014 and 2016), we mapped a total of six recurring landslides (Fig. 4b).

One earth flow, which records two post-1954 recurrences, illustrates a dynamic style of landslidefluvial interaction. The earth flow front (thickness $=4 \mathrm{~m}$ ) entered the Sillaro River in 2011, almost occluding the stream channel (Fig. 4d). By 2014, we observe that fluvial reworking had obliterated in-channel landslide deposits, leaving behind large blocks (b-axis up to $2 \mathrm{~m}$ ) of the Argille a Palombini Formation, which likely have prevented further fluvial undercutting, and locally have generated boulder-cascade channel morphology. The diamicton fabric of the Argille a Palombini, characterized by a pelitic matrix bearing limestone blocks (the so-called palombini), is possibly responsible for the observed fluvial response to sudden landslide sediment supply. Following this logic, we expect that most of the fine matrix was typically flushed downstream as suspended load.

At site B, multi-temporal mapping proved being critical for: (i) constraining landslide first appearance in photo year 1969 (Fig. 5a); (ii) elucidating landslide movement style and its interaction with the Sillaro River channel across decades; and (iii) identifying a small, previously undetected earth slide (Fig. 5f). In terms of size, landslide area increases from $7,800 \mathrm{~m}^{2}$ in the E-R inventory (Fig. 5e), to $12,900 \mathrm{~m}^{2}$, as mapped in photo year 2020 (Fig. 5f). Through the years, we note headward migration of the main headscarp and a progressive downslope movement of the main landslide body (thickness $=4 \mathrm{~m}$ ), with concurrent revegetation at the toe (e.g., Figures $5 \mathrm{~b}$ through $5 \mathrm{~d}$ ). Differently from site A, in this case we observe that the earth slide protrudes slowly into the Sillaro River channel and opposes resistance to fluvial undercutting. Accordingly, from 1996 (cf. Figures 5a and 5b) we start observing significant river deflection to northeast -- hence instability on the opposite valley side -and an increase in river planform sinuosity. To date, these dynamics continue altering the local morphology of the Sillaro River channel (e.g., Figures $5 c$ and $5 d$ ). As noted at site A, we also observe limestone blocks in the main channel bed, freshly supplied in proximity of the landslide front. 

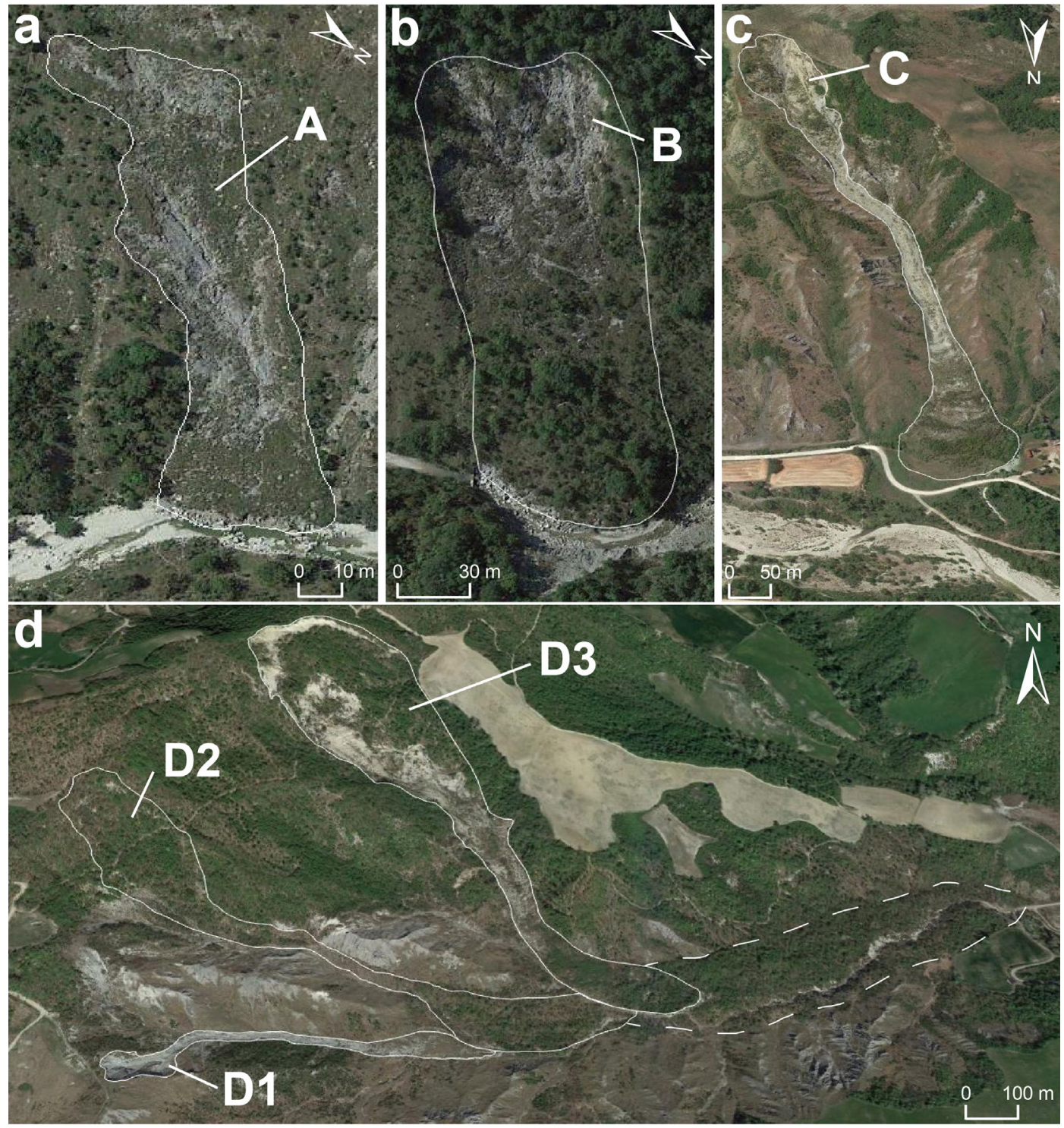

$100 \mathrm{~m}$
Fig. 3 - (a) Site A: unconfined, earth flow delivers sediment from an open-slope position within badlands morphology to the Sillaro River channel (source: Google Earth, 2014); (b) Site B: unconfined, rotational earth slide delivers sediment from an open-slope position in managed forest to the Sillaro River channel (source: Google Earth, 2018); (c) Site C: channelized earth flow developed within a ravine in badlands delivers sediment from a gully headwall, flows along a second-order gully channel, and stops by a road, behind older landslide deposits (source: Google Earth, 2017) (d) Site D: three earth flows (D1, D2, and D3), within a third-order tributary basin, which interfere with each other and deliver sediment to a gully channel that cuts through an older landslide deposit (dashed outline) (source: Google Earth 2020).
At site $\mathrm{C}$, multi-temporal mapping allowed elucidating the highly dynamic nature of this larger and more complex earth-flow system. At this site, the E-R inventory reports two historical earth-flow pulses -- one in late 2001, and one on May $5^{\text {th }}, 2019$ (Fig. 6h) -- as opposed to the eight activations documented between 1988 and 2020 (Fig. 6i). Overall, E-R mapping approach does a good job at delineating the total disturbed area, in that the existing combined polygon outline (Fig. 6h) is very similar to that we would get by merging all multi-temporal polygons together (Fig. 6i). However, the sum of the eight mapped polygons makes up an area of $113,700 \mathrm{~m}^{2}$, compared to the $42,400 \mathrm{~m}^{2}$ of the E-R inventory, implying a much larger sediment flux over the study period than previously expected.

In photo year 1976, along this steep tributary valley we observe old, partly vegetated landslide deposits that extend down to its mouth. We also observe that these deposits, emplaced at least before 1954, are incised by a gully channel draining north, then westward. This period of relative stability is followed by at least eight distinct channelized earth-flow pulses that have recurred between photo year 1988 and 2020 (Fig. 6). In some instances, earth flows travel down to the valley mouth, where they have damaged and altered the road course (photo years 1988, 2000, 2016, 2018 and 2020 in Fig. 6i), in others they have involved only the upper part of the gully system (e.g., 2006 and 2014) or a secondary drainage branch (2011). Largest occurrences, like those visible in 2000 and 2018, have produced significant headward migration of the gully network, causing loss of agricultural land. In no instance, recurring earth flows have reached the Sillaro River channel.

Site $\mathrm{D}$ is an earth flow-dominated tributary basin (1.2 $\mathrm{km}^{2}$ ), where the main valley floor stands out for being entirely occupied by a densely vegetated landslide deposit (Fig. 3d). In this context, multi-temporal mapping helped to elucidate that the nine coalescent "active" polygons (Fig. 7a): (i) are indeed the result of several landslides originating at multiple initiation sites between photo year 1954 and 2020 (Fig. 7b); and (ii) the distal portion of the valley trunk may be considered as an older depositional landslide feature. The latter interpretation is supported by the stability of the gully channel that has been cutting through it (Figures $8 \mathrm{~b}$ and $8 \mathrm{e}$ ), the lack of dislocation signs, 

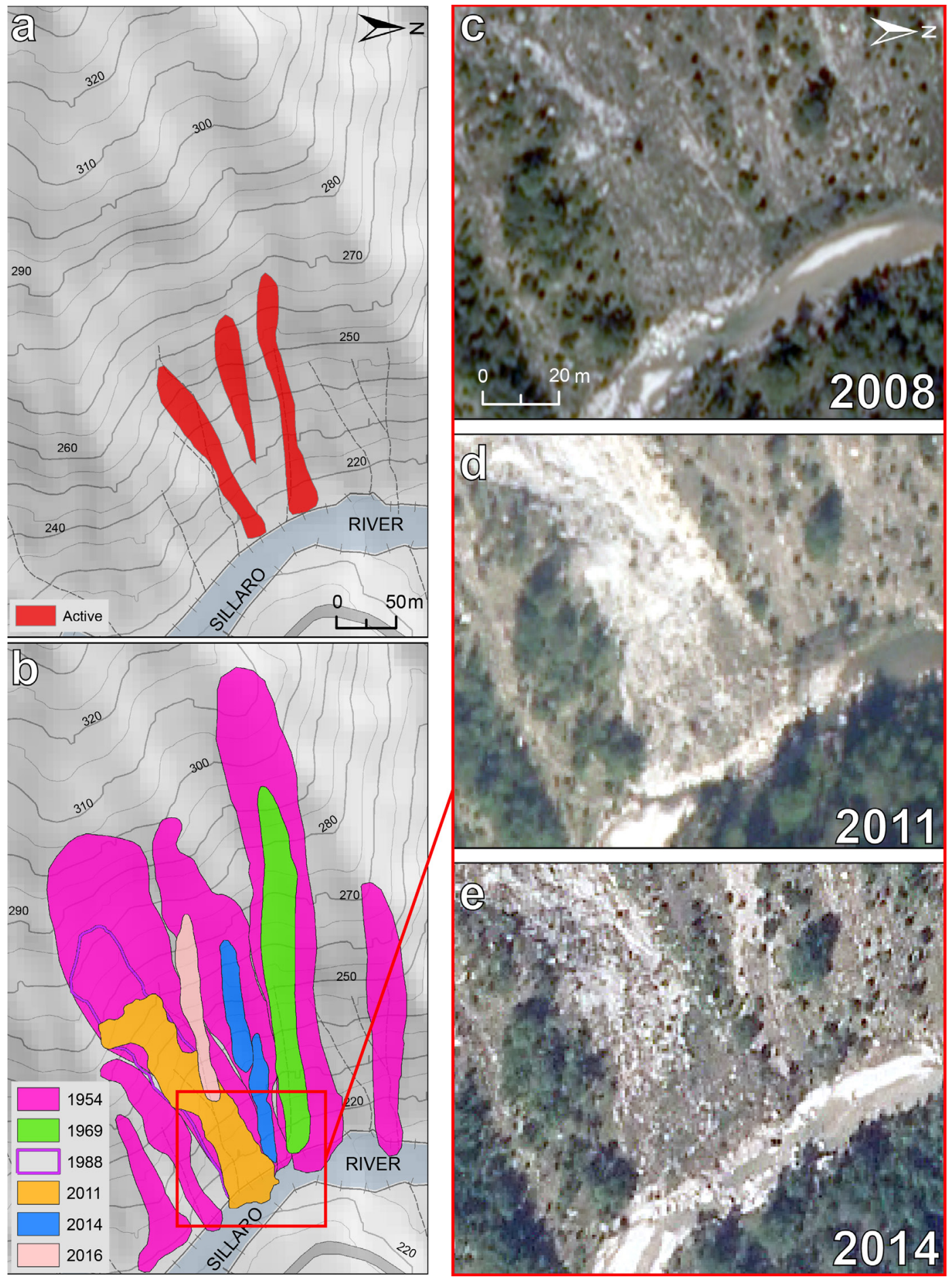

Fig. 4 - Site A: (a) landslide polygons of the EmiliaRomagna inventory; (b) corresponding multi-temporal landslide polygons mapped in this study; and closeup views of the landslide terminus (c) before (2008) (d) during (2011), and (e) after (2014) its advance in the Sillaro River channel. Note white limestone blocks of the Argille a Palombini Formation (Ligurian Domain) on the landslide surface and then forming lag deposits in the Sillaro River channel. In panel $b$, different colors indicate different photo years of landslide occurrence. Thick grey linework indicates roads. North arrow and scale in panel a apply also to panel b; north arrow and scale in panel $c$ apply also to panels $\mathrm{d}$ and $\mathrm{e}$.

and increasingly denser and undisturbed forest cover since photo year 1954 (Fig. 8). Some discrepancies between the regional and the site-specific multi-temporal mapping are also obvious along small lateral tributaries. For example, on the northern valley side we could not confirm landslide activity in any of the three distalmost lateral tributaries previously mapped as active sites (Fig. 7).

Interestingly, the sub-basin hosts a high diversity of landslide styles, including both recurring (sites D1 and D2) and episodic (site D3) movements. All three landslide initiation sites deliver material to the ephemeral gully network. D1 is a very narrow channel that experiences earth-flow activity in virtually all photo years, as testified by newly developed deposition lobes, lateral levees (Fig. 8c) and scarp headward migration (Figures $7 \mathrm{a}$ and $8 b)$. At D2, we observe recurring spoon-shaped landslide initiations developing into narrowly channelized earth flows (i.e., 1954, 1969, 2006, 2008, and 2011), the largest of which $\left(52,600 \mathrm{~m}^{2}\right)$ occurred in 1969 . These sediment slugs sometimes stop along the gully channel (2006 and 2011), sometimes reach the main valley floor, at the confluence with D1. Substantial vegetation regrowth at both the 

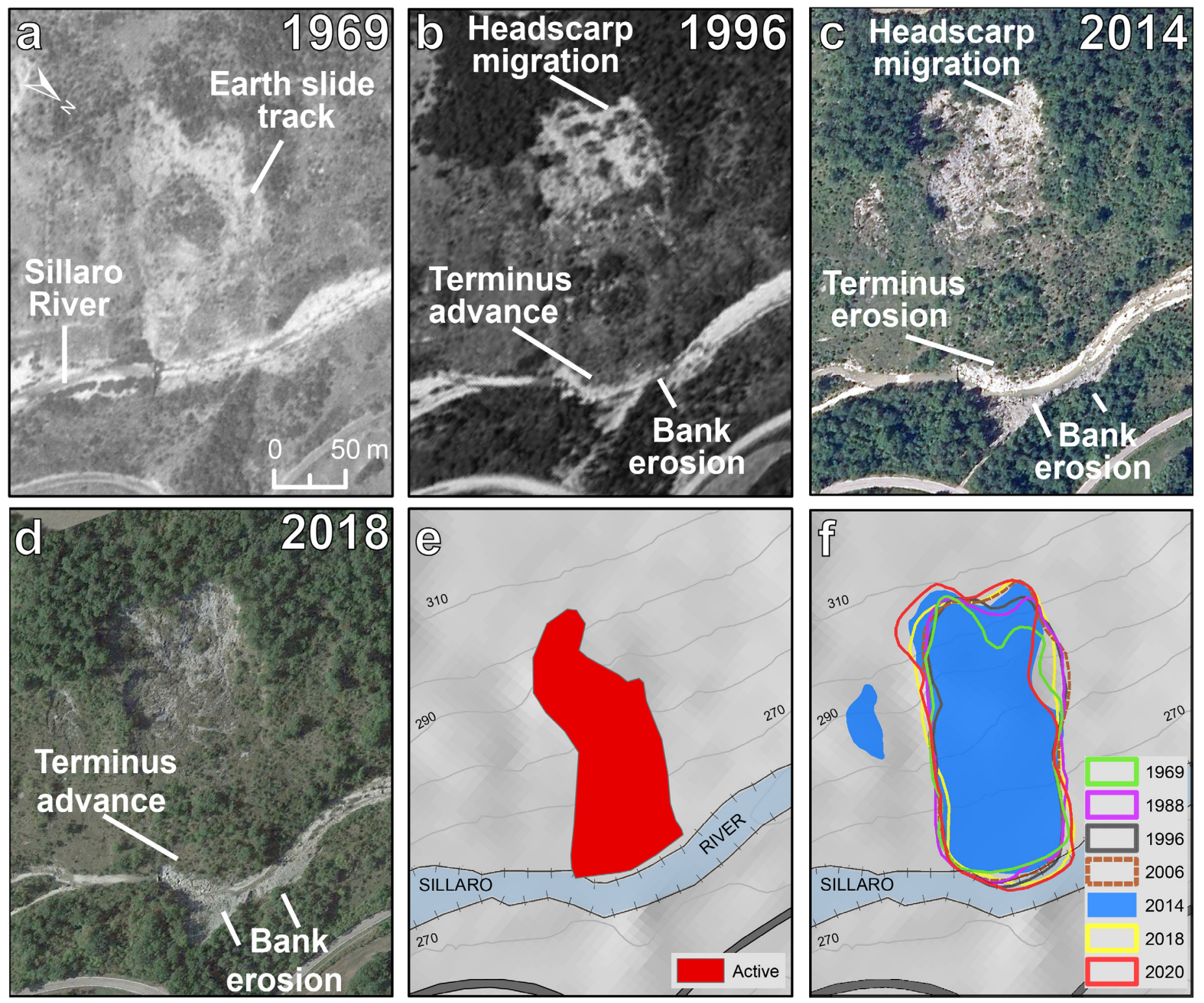

Fig. 5 - Site B: historical plan-view in photo year: (a) 1969; (b) 1996; (c) 2014; and (d) 2018. (e) Landslide polygon of the Emilia-Romagna inventory; and (f) corresponding multi-temporal landslide polygons mapped in this study. In panel f, different colors indicate different photo years of landslide extent. Note that initiation-transport and deposition zones are clearly visible and how landslide downslope movement induces river deflection to northeast, instability on the opposite valley side, and an increase of river planform sinuosity. Thick grey linework indicates roads. North arrow and scale in panel a apply to all panels.

initiation and the deposition zones is evident over time (cf. dashed yellow outline in Figures $8 \mathrm{a}$ and $8 \mathrm{~b}$ ). D3 is the largest landslide $\left(97,600 \mathrm{~m}^{2}\right)$ occurred between 1954 and 2020 at any of the four sites here examined. It was first observed in photo year 2016, initiated as a $25 \mathrm{~m}$-thick rotational slide (Fig. $8 \mathrm{~d}$ ), which transformed into an earth flow forcing the existing gully channel southward (Fig. 8b).

\section{DISCUSSION}

When considering a mapped landslide polygon of a multi-temporal inventory, critical information of interest to an end user, either for basic or applied purposes, include landslide size (e.g., area), how frequently landslide activity has occurred at that same location in a given time period and how landslide geometry developed in time. Indeed, landslide size, geometry and frequency modulate downslope/stream sediment flux and geomorphic disturbance, hence determine landslide hazard and risk to lives and man-made structures.

Comparative analysis between multi-temporal and E-R landslide mapping shows diverse outcomes across the four study sites. Inter-site variability, observed in terms of combined footprint area -- defined as the area of the polygon outline that results from merging all historically mapped landslides appeared between photo years 1954 and 2020 at a given site -- in part reflects landslide type and the number of recurrences mapped in the study period (Fig. 9). Combined footprint area is respectively 9 (site A) and 2 (site B) times larger than 

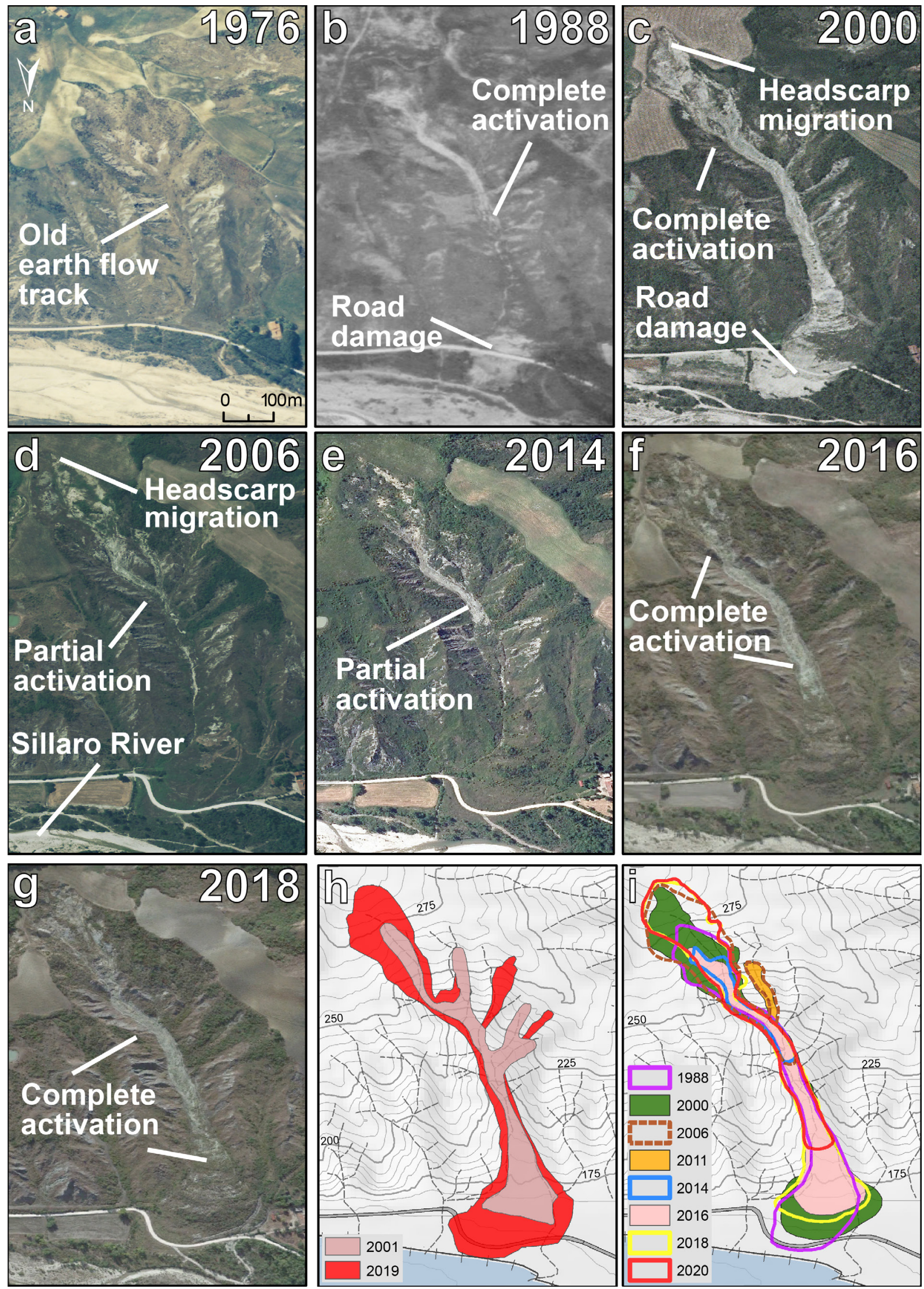

Fig. 6 - Site C: historical plan-view in photo year: (a) 1976; (b) 1988; (c) 2000; (d) 2006; (e) 2014; (f) 2016; and (g) 2018. (h) Landslide polygons of the Emilia-Romagna inventory; and (i) corresponding multi-temporal landslide polygons mapped in this study. Dashed black linework indicates drainage network. Thick grey linework indicates roads. In panel i, different colors indicate different photo years of landslide extent. Note road disturbance from photo year 1988 onward. North arrow and scale in panel a apply to all panels. 


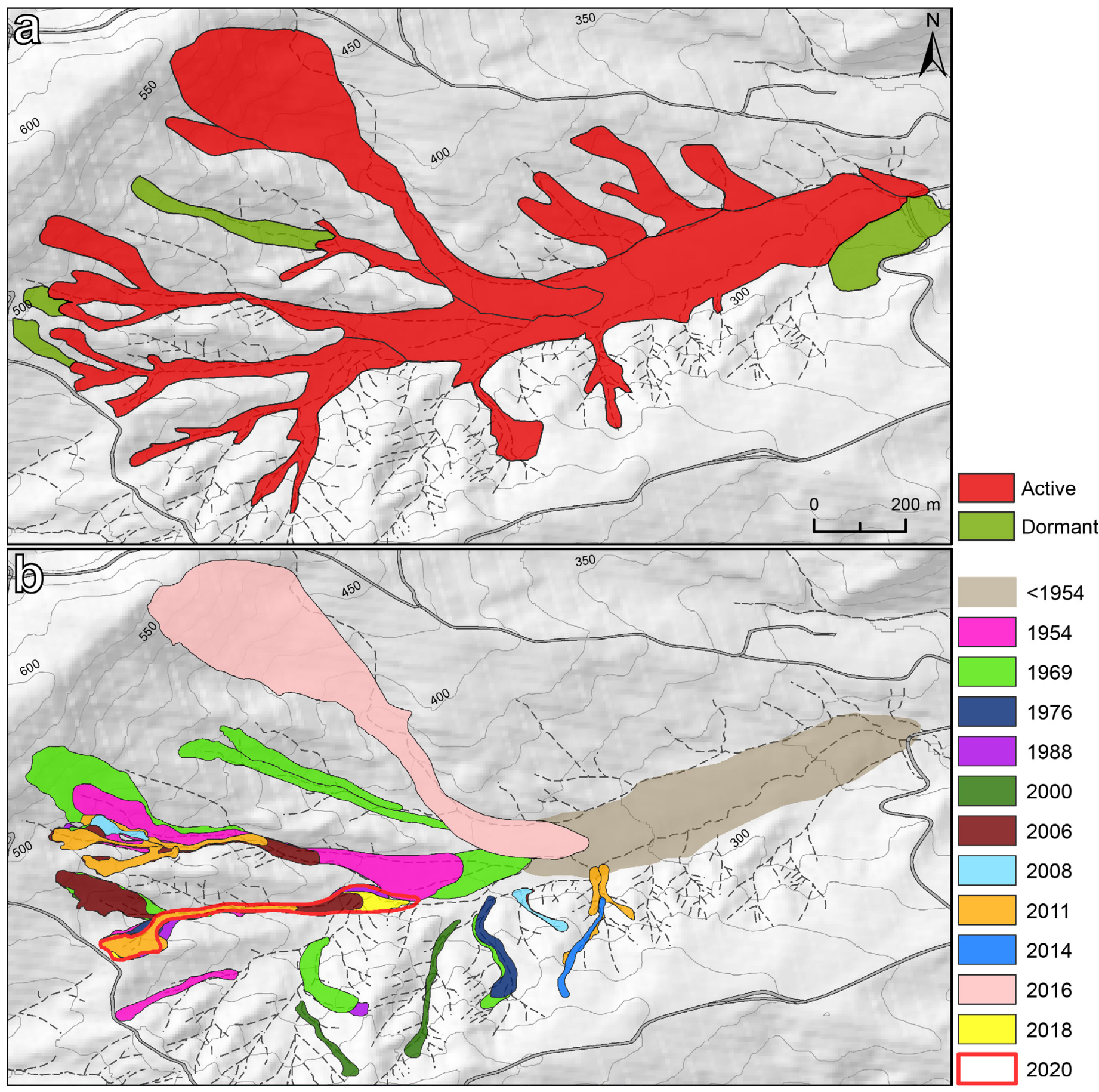

Fig. 7 - Site D: (a) landslide polygons of the Emilia-Romagna inventory; and (b) corresponding multi-temporal landslide polygons mapped in this study. In panel b, different colors indicate different photo years of landslide extent. Dashed black linework indicates drainage network. Thick grey linework indicates roads. North arrow and scale in panel a apply to all panels.

previously mapped in the E-R inventory (Table 4 and Figures $9 \mathrm{a}$ and $9 \mathrm{c}$ ). In the former, most of this difference is due to six landslide polygons mapped in photo year 1954; in the latter, this is related to progressive headscarp upslope migration, otherwise previously undetected. Combined footprint area is about the same at earth-flow site C (Table 4 and Fig. 9e), where the spatial extent of the two historically documented earth flows (Fig. 6h) substantially match that resulting from the eight multitemporal activations (Fig. 6i). At site D, combined footprint area in the E-R inventory is about 1.7 times larger than the corresponding multi-temporal case (Table 4 and Fig. 9g). In this context, the E-R inventory was critical for identifying the primary depositional feature on the sub-basin valley floor, whereas the multi-temporal approach allowed deciphering which portion of this deposit was indeed associated with post-1954 landslide activity (Figures 7 and 8).

Our findings indicated that the multi-temporal approach does not always result in mapping larger (or 


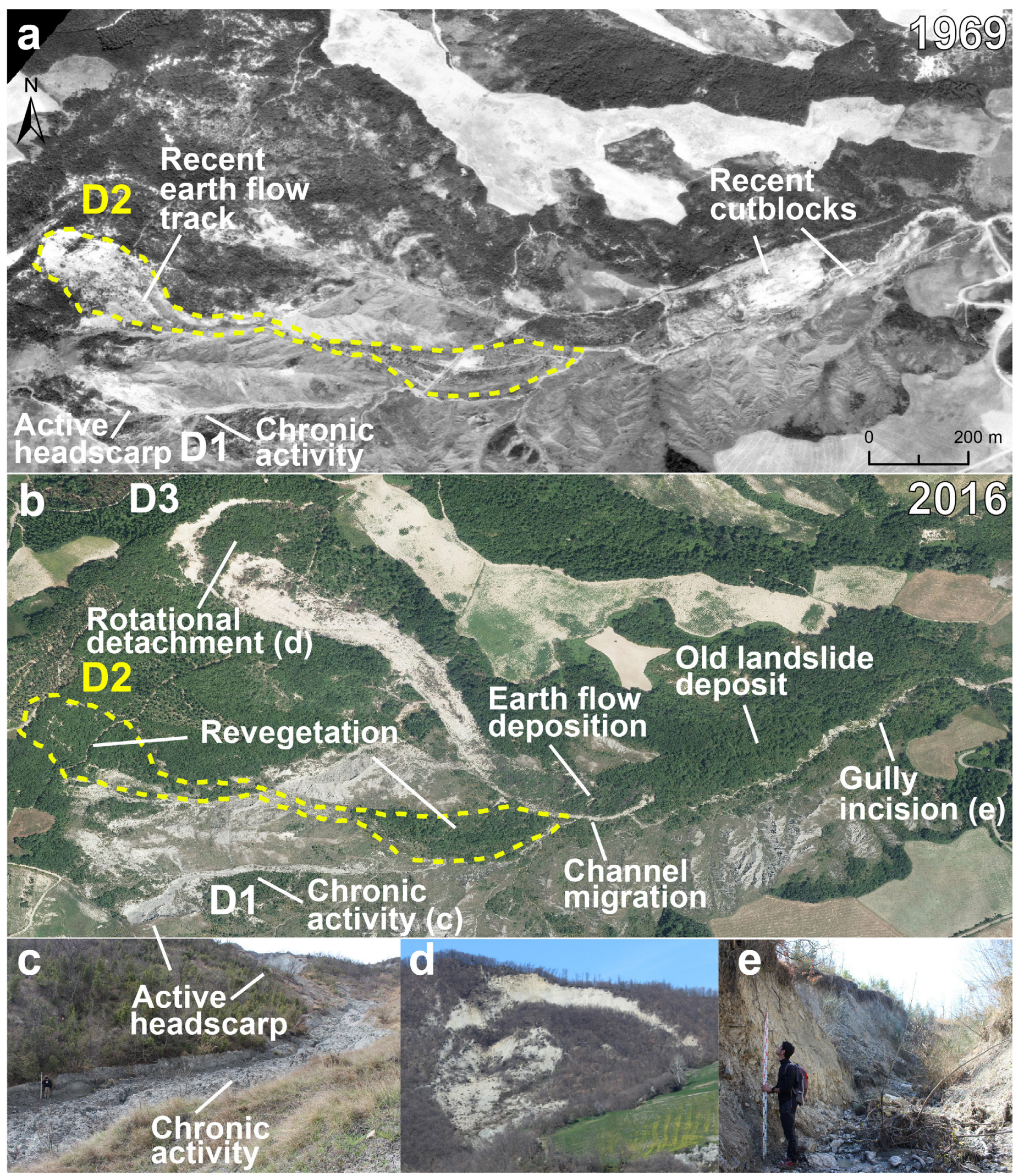

Fig. 8 - Vertical view of sub-basin D in photo year (a) 1969; and (b) 2016. Dashed yellow outline indicates the perimeter of an earth-flow track at site D2, occurred after photo year 1954 and before 1969, which appears completely revegetated in photo year 2016. Field, oblique views of: (c) active headscarp and earth-flow channel at site D1 (height of lateral levee $=1.5 \mathrm{~m}$ ); (d) rotational slide developing into an earth flow at site D3; and (e) gully channel cutting through old landslide deposit (thickness: 4 to 6 meters). 
TABLE 4

Landslide combined footprint area of the two inventories and landslide area across photo years obtained through the multi-temporal mapping approach (this study). At site B, landslide area across photo years refers to a single landslide feature evolving in time.

\begin{tabular}{|c|c|c|c|c|c|c|}
\hline & Inventory & Photo year & Site A & Site B & Site C & Site D \\
\hline \multirow[t]{2}{*}{ Combined footprint area $\left(\mathrm{m}^{2}\right)$} & E-R & & 5,700 & 7,800 & 42,400 & 399,300 \\
\hline & This study & & 48,800 & 15,200 & 37,900 & 239,300 \\
\hline \multirow[t]{13}{*}{ Landslide area $\left(\mathrm{m}^{2}\right)$} & This study & 1954 & 48,700 & & & 43,400 \\
\hline & & 1969 & 4,900 & 10,500 & & 96,200 \\
\hline & & 1976 & & & & 12,400 \\
\hline & & 1988 & 7,700 & 12,200 & 22,900 & 22,700 \\
\hline & & 1996 & & 11,900 & & \\
\hline & & 2000 & & & 28,900 & 25,400 \\
\hline & & 2006 & & 12,400 & 16,200 & 32,700 \\
\hline & & 2008 & & & & 3,200 \\
\hline & & 2011 & 5,600 & & 1,300 & 23,500 \\
\hline & & 2014 & 2,000 & 12,600 & 3,700 & 2,300 \\
\hline & & 2016 & 1,600 & & 15,300 & 97,600 \\
\hline & & 2018 & & 12,800 & 25,300 & 12,600 \\
\hline & & 2020 & & 12,900 & 16,700 & 14,300 \\
\hline
\end{tabular}

smaller) landslide polygons, or previously undetected landslides, but provides insights on process understanding. Consequently, an added value of this mapping approach lies in its ability to detect different styles of landsliding and improve the degree of inventory completeness in post1954 time (Fig. 9). For example, we could disentangle the origin of a combined footprint area in the E-R inventory: either as the result of multiple recurring landslides at site A (Fig. 9b), site C (Fig. 9f), and D (Fig. 9h), or as the progressive evolution of a single landslide scar at site $\mathrm{B}$ (Fig. 9d). In this context, the case of site D is instructive (Figures 7, 8 and 9h). Within this sub-basin, we could show that: (i) sites D1 and D2 have been continuously active since 1954; and (ii) site D3 is the result of a new earth flow, presently at the early stage of evolution. From an applied perspective, enhanced process-based understanding of landslide activity at the study sites provides critical insights on possible future scenarios of evolution, lending fundamental support for landslide hazard and risk assessment, as shown by previous geomorphological approaches (e.g., Cardinali et al., 2002; Van Westen et al., 2006; Wieczorek, 1984).

Information and inferences on process-response dynamics were drawn: (i) at landslide initiation sites, through observation of headscarp headward migration (as opposed to stability or vegetation regrowth), which implies downslope sediment supply; (ii) at landslide transport and deposition zones, the spatial pattern of revegetation through time, in conjunction with the development of gully channels, allowed inferring periods of stability; and (iii) changes at landslide terminus, allowed identifying new sediment pulses, exact sediment targets (e.g., fan, valley floor, and stream channel), as well as induced changes in channel morphology and geometry.
Combining similar process-based information at initiation, transport and deposition zones allows making inferences on landslide mobility and downslope/ downstream effects. For example, we found that landslides that initiate at gully headwalls (e.g., sites C, D1 and D2), move along confined gully channels and tend to stop before reaching a permanent stream channel. In particular, deliverability appears to be conditioned by previous landslides that have travelled along the same path and have formed depositional plugs, which now constitute a barrier to further landslide runout.

Although beyond the scope of this paper, the four study sites within the Sillaro River basin display a high temporal variability in landslide activity (cf. panels $b, d$, $f$ and $h$ in Fig. 9), suggesting complex responses to hydrometeorological forcing in relation to the history of each site, in terms of previous landslide activity, as well as natural and anthropogenic land cover dynamics.

\section{CONCLUSIONS}

With reference to the existing regional landslide inventory, we show that the multi-temporal approach proposed in this study can enhance relevant degree of completeness, through identification of previously undetected landslides, and reduce mapping uncertainties on existing polygons. In particular, by providing a dynamic view of landslide activity through time, the multi-temporal approach proved useful for gaining: (i) better time constraint to first time landslide occurrences and subsequent recurrences; (ii) improved estimation of landslide area, in relation to the episodic or recurring nature of activation(s); and (iii) insights on a surprisingly 


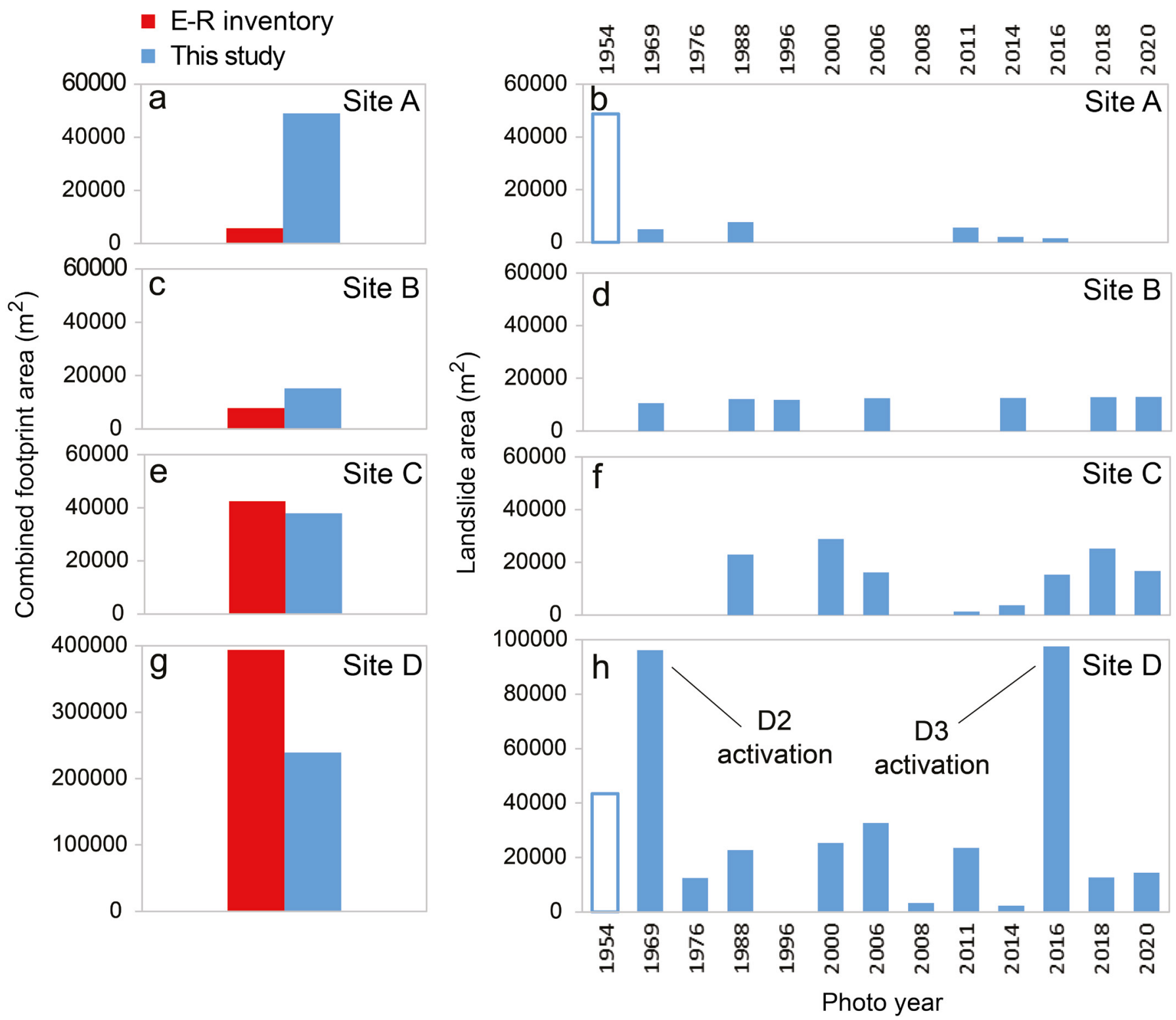

Fig. 9 - Comparison of landslide combined footprint area between the E-R inventory and this study (left hand-side panels). Landslide area across photo years obtained through the multi-temporal mapping approach (right hand-side panels). Empty bars indicate landslide areas of landslides visible on 1954 aerial photos, whose time of last activation is unknown.

wide range of hillslope-channel interactions that control the pace of landscape change.

Major improvements, in terms of landslide detection and quantification of the relevant areas, relate to gully systems and secondary tributary basins that experience recurring channelized earth-flows. In this context, our observations suggest that ephemeral gully systems may play a key role in the sediment budget of these clay-rich mountain settings. Specifically, we show that gullies can convey frequent earth-flow sediment slugs from headwall positions down to gully confluences (i.e., up to at least eight pulses in 30 years), where depositional lobes may pile up through time and choke the gully system, limiting the run out of subsequent earth-flow activations. During extended periods of stability, these sediment stores have shown to undergo partial reworking, through development and headward migration of newly-formed gully channels, which therefore promote sediment transfer downstream. To corroborate our preliminary interpretations and elucidate further these dynamics of gully recharge and evacuation, we believe ad hoc monitoring efforts are needed.

To constrain landslide-derived sediment fluxes over more representative spatial scales, future work in the Sillaro River will aim at extending the present multitemporal mapping experiment at the basin scale, while complementing it with an assessment of landslide thickness, hence volumes of mobilized debris.

\section{ACKNOWLEDGEMENTS}

This work was partly funded by Fondazione Cassa di Risparmio in Bologna through 2018/0348 BEDFLOW and 2019/0228 BEDFLOW 
PLUS projects. SP was funded through a PhD scholarship of the Italian Ministry of University (cycle XXXIV). We thank Giovanna Daniele, Giulio Ercolessi, and the Archivio Cartografico della Regione EmiliaRomagna for providing information on historical aerial imagery and the Emilia-Romagna landslide inventory.

\section{REFERENCES}

ARPAE (Agenzia prevenzione ambiente energia Emilia-Romagna) (2021) - Annali idrologici. https://www.arpae.it/it/temi-ambientali/ meteo/report-meteo/annali-idrologici (Last accessed: $25^{\text {th }}$ March 2021).

Baum R.L. \& Reid M.E. (1995) - Geology, hydrology and mechanics of a slow-moving, clay-rich landslide, Honolulu, Hawaii. In Haneberg W.C. \& Anderson S.A. (eds.), Clay and Shale Slope Instability. Geological Society of America, Reviews in Engineering Geology, 10, 79-105.

Bayer B., Simoni A., Mulas M., Corsini A. \& Schmidt D. (2018) Deformation responses of slow moving landslides to seasonal rainfall in the Northern Apennines, measured by InSAR. Geomorphology, 308, 293-306.

Bekaert D.P.S., Handwerger A.L., Agram P. \& Kirschbaum D.B. (2020) - InSAR-based detection method for mapping and monitoring slow-moving landslides in remote regions with steep and mountainous terrain: An application to Nepal. Remote Sensing of Environment, 249, 111983.

Benini A., De Nardo M.T., Severi P., Borsetti A.M., Negri A. \& Vaiani S.C. (2009) - Note Illustrative della Carta Geologica d'Italia alla scala 1:50.000, F. 238 Castel San Pietro Terme. 124 pp., S.EL.CA. Firenze.

Berti M., Martina M.L.V., Franceschini S., Pignone S., Simoni A. \& Pizziolo M. (2012) - Probabilistic rainfall thresholds for landslide occurrence using a Bayesian approach. Journal of Geophysical Research, 117(F4), F04006.

Berti M. \& Simoni A. (2010) - Field evidence of pore pressure diffusion in clayey soils prone to landsliding. Journal of Geophysical Research, 115(F3), F03001.

Bertolini G. \& Pizziolo M. (2008) - Risk assessment strategies for the reactivation of earth flows in the Northern Apennines (Italy). Engineering Geology, 102(3-4), 178-192.

Bettelli G., Panini F., Fioroni C., Nirta G., Remitti F., Vannucchi P. \& Carlini M. (2012) - Revisiting the Geology of the "Sillaro Line", Northern Apennines, Italy. Rendiconti Online della Società Geologica Italiana, 22, 14-17.

Bovis M.J. \& Jakob M. (1999) - The role of debris supply conditions in predicting debris flow activity. Earth Surface Processes and Landforms, 24(11), 1039-1054.

Brardinoni F., Cavalli M., Heckmann T., Liebault F. \& Rimbock A. (2015) - Guidelines for assessing sediment dynamics in alpine basins and channel reaches. SedAlp WP4 Final Report, Alpine Space, $71 \mathrm{pp}$.

Brardinoni F., Church M., Simoni A. \& Macconi P. (2012) - Lithologic and glacially-conditioned controls on debris-flow sediment dynamics. Geology, 40, 455-458.

Brardinoni F., Hassan M.A., Rollerson T. \& Maynard D. (2009) Colluvial sediment dynamics in mountain drainage basins. Earth and Planetary Science Letters, 284(3-4), 310-319.

Brummer C.J. \& Montgomery D.R. (2003) - Downstream coarsening in headwater channels. Water Resources Research, 39(10), 1294.

Cardinali M., Reichenbach P., Guzzetti F., Ardizzone F., Antonini G., Galli M., Cacciano M., Castellani M. \& Salvati P. (2002) A geomorphological approach to the estimation of landslide hazards and risks in Umbria, Central Italy. Natural Hazards and Earth System Sciences, 2(1-2), 57-72.

Colesanti C. \& Wasowski J. (2006) - Investigating landslides with space-borne Synthetic Aperture Radar (SAR) interferometry. Engineering Geology, 88(3-4), 173-199.

Corsini A., Borgatti L., Cervi F., Dahne A., Ronchetti F. \& Sterzai P. (2009) - Estimating mass-wasting processes in active earth slides - earth flows with time-series of High-Resolution DEMs from photogrammetry and airborne LiDAR. Natural Hazards Earth System Sciences, 9(2), 433-439.
Crovelli R.A. (2000) - Probability models for estimation of number and costs of landslides. U.S. Geological Survey Open File Report 00-249, $24 \mathrm{pp}$.

Cruden D.M. \& Varnes D.J. (1996) - Landslide types and processes. In: Turner A.K. \& Schuster R.L. (eds.), Landslides, Investigation and Mitigation. Transportation Research Board, Special Report 247. National Academy Press, 36-75.

Finnegan N.J., Broudy K.N., Nereson A.L., Roering J.J., Handwerger A.L. \& Bennett G. (2019) - River channel width controls blocking by slow-moving landslides in California's Franciscan mélange. Earth Surface Dynamics, 7(3), 879-894.

Green K.G., Brardinoni F. \& Alila Y. (2013) - Channel morphology and bed-load yield in fluvial, formerly-glaciated headwater streams of the Columbia Mountains, Canada. Geomorphology, 188, 96-109.

Guzzetti F., Cardinali M., Reichenbach P. \& Carrara A. (2000) Comparing Landslide Maps: A Case Study in the Upper Tiber River Basin, Central Italy. Environmental Management, 25(3), 247-263.

Guzzetti F., Galli M., Reichenbach P., Ardizzone F. \& Cardinali M. (2006) - Landslide hazard assessment in the Collazzone area, Umbria, Central Italy. Natural Hazards Earth System Sciences, 6(1), 115-131.

Guzzetti F., Reichenbach P., Cardinali M., Galli M. \& Ardizzone F. (2005) - Probabilistic landslide hazard assessment at the basin scale. Geomorphology, 72, 272-299.

Hassan M.A., Bird S., Reid D., Ferrer-Boix C., Hogan D., Brardinoni F. \& Chartrand S. (2019) - Variable hillslope-channel coupling and channel characteristics in forested mountain streams of glaciated landscapes. Earth Surface Processes and Landforms, 44(3), 736751.

Hovius N., Stark C.P. \& Allen P.A. (1997) - Sediment flux from a mountain belt derived by landslide mapping. Geology, 25(3), 231234.

May C.L. \& Gresswell R.E. (2003) - Processes and rates of sediment and wood accumulation in headwater streams of the Oregon Coast Range, USA. Earth Surface Processes and Landforms, 28(4), 409-424.

Maynard D. (1991) - Tsitika River Watershed Sediment Source Inventory. Unpublished internal report. Vancouver Region, British Columbia Ministry of Forests.

Nakamura F., Swanson F.J. \& Wondzell S.M. (2000) - Disturbance regimes and riparian systems - a disturbance-cascade perspective. Hydrological Processes, 14(16-17), 2849-2860.

Nereson A.L. \& Finnegan N.J. (2018) - Drivers of earthflow motion revealed by an 80 yr record of displacement from Oak Ridge earthflow, Diablo Range, California, USA. Geological Society of America Bulletin, 131(3-4), 389-402.

Pavanelli D., Cavazza C., Lavrnic S. \& Toscano A. (2019) - The LongTerm Effects of Land Use and Climate Changes on the HydroMorphology of the Reno River Catchment (Northern Italy). Water, 11, 1831.

Piacentini D., Troiani F., Daniele G. \& Pizziolo M. (2018) - Historical geospatial database for landslide analysis: the Catalogue of Landslide OCcurrences in the Emilia-Romagna Region (CLOCkER). Landslides, 15(4), 811-822.

Pizziolo M., Bernardi M., Daniele G., Generali M. \& Piacentini D. (2015) - Landslide occurrences during the high-intensity rainfall event of March-April 2013 in the Emilia-Romagna region (North Apennines, Italy). In: Lollino G., Manconi A., Guzzetti F., Culshaw M., Bobrowsky P. \& Luino F. (eds), Engineering Geology for Society and Territory - Volume 5. Springer, 777-780.

Preciso E., Salemi E. \& Billi P. (2012) - Land use changes, torrent control works and sediment mining: effects on channel morphology and sediment flux, case study of the Reno River (Northern Italy). Hydrological Processes, 26 (8), 1134-1148.

Regione Emilia-Romagna (2021) - Cartografia del dissesto della Regione Emilia-Romagna. https://geo.regione.emilia-romagna.it/ cartografia_sgss/user/viewer.jsp? service=dissesto (Last accessed: $8^{\text {th }}$ April 2021).

Reid L.M. \& Dunne T. (1996) - Rapid Evaluation of Sediment Budgets. Catena Verlag, Reiskirchen, 164 pp.

Roering J.J., Stimely L.L., Mackey B.H. \& Schmidt D.A. (2009) Using DInSAR, airborne lidar, and archival air photos to quantify landsliding and sediment transport. Geophysical Research Letters, 36(19), L19402. 
Schuerch P., Densmore A.L., McArdell B.W. \& Molnar P. (2006) - The influence of landsliding on sediment supply and channel change in a steep mountain catchment. Geomorphology 78(3-4), 222-235.

Simoni A., Ponza A., Picotti V., Berti M. \& Dinelli E. (2013) - Earthflow sediment production and Holocene sediment record in a large Apennine catchment. Geomorphology, 188, 42-53.

Van Westen C.J., van Asch T.W. \& Soeters R. (2006) - Landslide hazard and risk zonation-why is it still so difficult?. Bulletin of
Engineering geology and the Environment, 65(2), 167-184.

Wieczorek G.F. (1984) - Preparing a detailed landslide-inventory map for hazard evaluation and reduction. Bulletin of the Association of Engineering Geologists, 21(3), 337-342.

Zattin M., Picotti V. \& Zuffa G.G. (2002) - Fission-track reconstruction of the front of the Northen Apennine thrust wedge and overlying Ligurian Unit. American Journal of Science, 302(4), 346-379. 